\title{
IMPLEMENTASI KEBIJAKAN ASIMILASI NARAPIDANA DI TENGAH PANDEMI COVID-19
}

\author{
Sri Marthaningtiyas \\ Pembimbing Kemasyarakatan Balai Pemasyarakatan Kelas II Pati \\ srimarthaningtiyas@gmail.com
}

\begin{abstract}
ABSTRAK
Kebijakan Menteri Hukum dan HAM RI Nomor: 10 tahun 2020 tentang pengeluaran dan pembebasan narapidana melalui proses asimilasi dan integrasi dalam menanggulangi pandemi Covid-19 menuai kontroversi. Tidak hanya narapidana umum, wacana pembebasan narapidana khusus juga ikut menjadi kontroversi. Sebagian kalangan menilai keputusan tersebut merupakan langkah yang tepat guna menghormati hukum dalam Sistem Peradilan Pidana. Metode penelitian yang digunakukan oleh penulis adalah pendekatan kualitatif secara yuridis empiris. Tujuan penelitian adalah untuk mengetahui dan memahami tentang pelaksanaan asimilasi narapidana di masa pandemi Covid-19. Kebijakan ini secara cepat telah berhasil mengeluarkan 40.330 orang dari Lapas dan Rutan di seluruh Indonesia, sehingga sedikit memberikan kontibusi untuk melonggarkan tingkat overcrowded meskipun masih jauh saat ini masih terjadi overcrowded dengan persentase dari $103 \%$ sebelum kebijakan diterapkan menjadi $75 \%$ setelah kebijakan di implentasikan.

Kata kunci: asimilasi, narapidana, covid-19
\end{abstract}

\begin{abstract}
The policy on The Minister of Law and Human Rights Number 10 of 2020 on the release of prisoners through assimilation and integration process for tackling the Covid-19 pandemic is controversial. Not only general inmates, but the discourse of the release of special inmates is also controversial. Some people consider the decision to be an appropriate way to respect the law in the Criminal Justice System. The research method was an empirically qualitative approach. It aimed to gain and understand the implementation of the assimilation of prisoners during the Covid-19 pandemic. This policy had quickly succeeded in expelling 40,330 people from Lapas and Rutan throughout Indonesia, making little contribution to easing the overcrowded rate although it was still far from overcrowded with a percentage of $103 \%$ before the policy was implemented to $75 \%$ after the policy was implemented.

Keyword: assimilation, prisoners, the covid-19
\end{abstract}

Sri Marthaningtivas, Impilmentasi Kebijakasi Asimilasi... 


\section{PENDAHULUAN}

Virus Covid-19 Virus ini merupakan keluarga besar virus yang menyebabkan infeksi pernapasan. ${ }^{1}$ Vaksin untuk mencegah Covid-19. World Health Organization (WHO) telah menetapkan wabah virus corona (covid-19) sebagai pandemi. Penetapan Covid-19 sebagai pandemi global tanggal 12 Maret 2020 oleh Direktur Jenderal WHO, Dr Tedros Adhanom Ghebreyesus².

Presiden Jokowi saat konferensi pers di Istana Kepresidenan Bogor pada Selasa, 31 Maret 2020 lalu. Penetapan ini dilakukan lewat penerbitan Keputusan Presiden Nomor 11 Tahun 2020 tentang Penetapan Bencana Non Alam Penyebaran Corona Virus Disease 2019 (Covid-19) sebagai Bencana Nasional. Penyebaran covid-19 sangat mengkhawatirkan.

Kebijakan dalam rangka mengatasi dan meminimalisasi percepatan penyebaran virus ini diambil oleh pemerintah Indonesia melalui kewajiban masyarakat untuk menerapkan program pola hidup sehat, social distancing dan physical distancing kepada seluruh masyarakat, tidak terkecuali masyarakat yang menjadi penghuni Lembaga Pemasyarakatan (Lapas) dan Rumah Tahanan Negara (Rutan).

Upaya kebijakan penanggulangan kejahatan menurut G.P. Hoefnagels dapat ditempuh menjadi dua jalan yaitu penal (hukum pidana) yang menitikberatkan pada sistem "repressive" berupa (penindasan atau pemberantasan) atas setelah kejahatan yang terjadi dan nonpenal (di luar hukum pidana) menitikberatkan pada sifat "preventive" berupa pencegahan/pengendalian sebelum kejahatan terjadi. Jalan non penal mempunyai sasaran utama dalam menangani faktor-faktor kondusif yang

\footnotetext{
${ }^{1}$ World Health Organization, "Situation Report - 42, https://www.who.int/docs/defaultsource/coronaviruse/situation-reports/20200314-sitrep-54-covid19.pdf?sfvrsn=dcd46351_2, diakses 01 Oktober 2020

${ }^{2}$ World Health Organization, "Novel Coronavirus (2019- nCoV) Situation Report - 54", 2020
} 
berpusat pada masalah atau kondisi sosial yang terjadi secara langsung dan tidak langsung yang dapat mengakibatkan suatu kejahatan. ${ }^{3}$

Lapas dan Rutan merupakan sebuah institusi tertutup yang memiliki tingkat hunian tinggi, sangat rentan terhadap penyebaran dan penularan Corona Virus Disease 2019 (Covid19). Isi Lapas/Rutan per 31 Maret 2020 di seluruh Indonesia sekitar 270.231 orang (sumber: Sistem Database Pemasyarakatan) sedangkan kapasitas hunian hanya bisa menampung sebanyak 130.000 orang. Artinya tingkat "over crowded" sebesar $103 \%$. Bahkan di beberapa tempat misalnya Lapas Kelas I Cipinang, Lapas Banjarmasin atau Lapas Bagansiapi-api hampir mencapai $400 \%$.

Kebijakan pengeluaran dan pembebasan narapidana melalui proses asimilasi dan integrasi menuai kontroversi. Tidak hanya narapidana umum, namun wacana pembebasan narapidana khusus juga ikut menjadi kontroversi. Sebagian kalangan menilai keputusan tersebut merupakan langkah yang tepat guna menghormati hukum dalam Sistem Peradilan Pidana. Di sisi lain, tidak sedikit yang justru menyayangkan keputusan tersebut dengan berbagai alasan, khususnya kekhawatiran akan dampak kerentanan aspek sosial dan keamanan selepas narapidana tersebut bergerak bebas di masyarakat. Publik merasa ragu, bahwa upaya pembebasan narapidana merupakan langkah yang tepat dalam mencegah peyebaran dan penularan covid-19.

\section{METODE PENELITIAN}

1. Pendekatan Penelitian

Dalam penulisan penelitian tesis ini metode penelitian yang dilakukan oleh peneliti adalah pendekatan secara yurdis empiris. Pendekatan secara yuridis empiris dilakukan dengan mempelajari peraturan perundang-undangan, konsep-konsep, teori-teori serta implementasi yang berhubungan dengan permasalahan yang akan diteliti tentang

${ }^{3}$ Nawawi Barda, “Bunga Rampai Kebijakan Hukum Pidana: Perkembangan Penyusunan Konsep KUHP Baru”, Kencana, Jakarta, 2008, hlm 48 
kebijakan asimilasi narapidana di tengah pandemi covid-19 dalam perspektif sistem pemasyarakatan.

2. Spesifikasi Penelitian

Dalam penyusunan dan penulisan tesis ini akan dipergunakan salah satu spesifikasi penelitian yaitu deskriptif analitis. Bersifat deskriptif analitis karena penelitian ini dimaksudkan untuk memberikan gambaran secara rinci, sistematis dan menyeluruh mengenai segala sesuatu baik perundang-undangan maupun teori-teori hukum. Penelitian ini akan menggambarkan mengenai kebijakan asimilasi narapidana di tengah pandemi covid-19 dalam perspektif sistem pemasyarakatan.

3. Jenis Data

Metode pendekatan yuridis empiris adalah metode yang digunakan dalam penelitian ini, dengan melakukan pengumpulan data berasal dari data primer sebagai data utama dan data sekunder sebagai data pendukung. Data penelitian didapatkan dari informan yang berasal dari aparat penegak hukum dan instansi terkait terutama UPT pemasyarakatan yang berada di wilayah jangkauan Balai Pemasyarakatan Kelas IIB Pati, yaitu wilayah ex-karisidenan Pati yang meliputi enam Kabupaten yaitu Pati, Kudus, Jepara, Rembang, Blora, dan Grobogan. Adapun informan yang diwawancari dalam penelitian ini adalah :

1. Kepala Subsie Bimbingan Klien Dewasa Balai Pemasyarakatan Kelas II Pati

2. Kepala Subsie Bimbingan Klien Anak Balai Pemasyarakatan Kelas II Pati

3. Pembimbing Kemasyarakatan Balai Pemasyarakatan Kelas II Pati 
4. Klien pemasyarakatan/ narapidana yang mendapatkan hak asimilasi di tengah pandemi covid-19 yang bertempat tinggal di Kabupaten Pati, Kudus, Jepara, Blora, Rembang, Grobogan.

Penentuan informan ini dilakukan secara purposive sampling. Purposive sampling adalah tekhnik pengambilan sampel sumber data dengan pertimbangan tertentu. Sumber data yang dipilih yaitu orangorang yang dianggap sebagai orang yang langsung mendapatkan dampak asimilasi pengeluaran narapidana di wilayah se-eks Karisidenan Pati dan instansi penegak hukum yang langsung mengetahui permasalahan yang akan diteliti atau juga yang berwenang dalam masalah tersebut.

\section{PEMBAHASAN DAN HASIL PENELITIAN}

\section{Kondisi Overcrowded Lapas dan Rutan di Indonesia}

Permasalahan overcrowded/ overcapasitas Lapas dan Rutan di Indonesia hingga saat ini menjadi pekerjaan rumah bagi Pemerintah yang sangat sulit untuk mengatasinya. Berdasarkan situs https://www.prisonstudies.org, diakses tanggal 1 Oktober 2020 Indonesia merupakan negara peringkat ke 9 (sembilan) terbanyak dari 223 negara di dunia saat ini dengan jumlah penghuni Lapas dan Rutan yang tersebar di seluruh daerah. Data jumlah penghuni penjara di dunia dapat dilihat pada tabel 1 berikut $^{4}$ :

\begin{tabular}{ccc}
\hline Peringkat & Negara & $\begin{array}{c}\text { Jumlah Narapidana } \\
\text { dan Tahanan }\end{array}$ \\
\hline $\boldsymbol{l}$ & United States of America & 2.094 .000 \\
\hline
\end{tabular}

${ }^{4}$ World Prison Brief, https://www.prisonstudies.org, diakses 01 Oktober 2020 


\begin{tabular}{lcc}
\hline $\mathbf{2}$ & China & 1.710 .000 \\
$\mathbf{3}$ & Brazil & 755.274 \\
$\mathbf{5}$ & Rusia & 493.310 \\
$\mathbf{6}$ & India & 478.600 \\
$\mathbf{7}$ & Thailand & 381.454 \\
$\mathbf{8}$ & Turki & 281.094 \\
$\mathbf{9}$ & Iran & 240.000 \\
$\mathbf{1 0}$ & Indonesia & 231.848 \\
\hline
\end{tabular}

Hingga saat ini jumlah narapidana dan tahanan Lapas dan Rutan di Indonesia menunjukkan peningkatan jumlah yang sangat signifikan. Tabel 2 di bawah ini menunjukkan gambaran peningkatan jumlah tahanan dan narapidana di Indonesia selama lima tahun terakhir yaitu mulai tahun 2015 sampai 2019.

\section{Tabel 2.}

Data Jumlah Tahanan dan Narapidana di Indonesia 2015-2019 (Sumber Sistem Database Pemasyarakatan, Ditjen Pemasyarakatan, 2020) ${ }^{5}$

${ }^{5}$ Website SMS Gateway Kemenkumham: http://smslap.ditjenpas.go.id/public/grl/current/monthly, 20 Oktober, 2020 


\begin{tabular}{|c|c|c|c|c|c|c|}
\hline Tahun & Tahanan & Narapidana & $\begin{array}{c}\text { Jumlah Total } \\
\text { Penghuni }\end{array}$ & Kapasitas Hunia & $\begin{array}{c}\text { Selisih Jumlah } \\
\text { penghuni dengan } \\
\text { kapasitas hunian }\end{array}$ & $\begin{array}{c}\text { Persentase } \\
\text { overcrowded }\end{array}$ \\
\hline 2015 & 57.547 & 119.207 & 176.754 & 119.797 & 56.967 & 47,55 \\
\hline 2016 & 65.554 & 138.997 & 204.551 & 119.797 & 84.757 & 70,75 \\
\hline 2017 & 70.739 & 161.342 & 232.081 & 123.481 & 108.600 & 87,95 \\
\hline 2018 & 72.106 & 183.274 & 255.380 & 133.769 & 121.611 & 90,91 \\
\hline 2019 & 64.005 & 201.643 & 265.648 & 133.769 & 131.879 & 98,59 \\
\hline
\end{tabular}

Berdasarkan tabel diatas dapat dilihat dalam kurun waktu lima tahun jumlah penghuni Lapas dan Rutan di Indonesia selalu naik meskipun terjadi penambahan kapasitas hunian dengan melakukan pembangunan Lapas dan Rutan baru pada tahun 2017 dan 2018, namun hal ini tidak mampu menyelesaikan peningkatan angka persentase overcrowded yang ada di Lapas dan Rutan.

Berbagai penyebab kepadatan hunian Lapas dan Rutan di Indonesia, karena faktor-faktor berikut ini:

a. Penahanan pra persidangan yang berlebihan serta pemidanaan eksesif terhadap kejahatan tindak pidana ringan (minor offences), kejahatan tanpa korban (victimiess crime)

b. Pemikiran dalam penentuan putusan oleh hakim bahwa pemidanaan berupa pidana penjara (Custodial/ perampasan kemerdekaan) akan memberikan suatu efek jera bagi pelaku, hal ini memperlihatkan bahwa hakim belum adanya kesadaran dalam penjatuhan pidana penjara merupakan suatu upaya terakhir jika upaya lain tidak berhasil.

c. Kebijakan pemidanaan yang dirancang oleh Dewan Perwakilan Rakyat (DPR) dan Pemerintah dalam pengaturan perundang-undangan yang berisikan pidana sebagai suatu alat yang bersifat memaksa para pelanggar hukum untuk di tempatkan di dalam Lapas dan Rutan 
d. Adanya Peraturan Pemerintah Nomor 99 Tahun 2012 yang merupakan perubahan kedua atas Peraturan Pemerintah Nomor 32 Tahun 1999 tentang Syarat dan Tata Cara Pelaksanaan Hak Warga Binaan Pemasyarakatan Peraturan ini berisikan ketentuan khusus pemberian hak terhadap narapidana tindak pidana khusus tertentu seperti tindak pidana korupsi, tindak pidana narkotika diatas 5 (lima) tahun serta tindak pidana terorisme. Sehingga proses asimilasi dan reintegrasi tidak berjalan optimal.

e. Alternatif penahanan serta pidana denda seakan diabaikan oleh hakim, dan untuk pidana denda saat ini hanya penyesuaian batasan untuk tindak pidana ringan dengan jumlah besaran denda di dalam KUHP

f. Nilai-nilai pemenjaraan sangat kental berlaku pada politik hukum pidana yang berlaku di Indonesia, sehingga menyebabkan adanya pasal yang bersifat overkriminalisasi.

g. Pemberian pasal dalam penetuan tersanngka yang terlibat tindak pidanan Narrkotika, berdasarkan Undang-Undang RI No 35 Tahun 2009 tentang Narkotika, ketika dijumpai di lapangan yang seharusnya pemakai dikenakan pasal pemakai, namun kenyataannya mereka dikenakan pasal pengendar/bandar, demikian juga sebaliknya. Putusan vonis hakim juga menentukan overcrowded Lapas dan Rutan, dimana baik pemakai serta bandar/pengedar dikenakan vonis pidana penjara. Hal ini terlihat dari database pemasyarakatan, data menunjukkan bahwa penghuni di Lapas dan Rutan adalah tindak pidana Narkotika terbanyak dibandingkan tindak pidana umum dan tindak pidana khusus lainnya yaitu sebanyak 142.276 orang (terdiri dari 47.383 pemakai dan 94.438 bandar/pengedar), sedangkan untuk tindak pidana umum sekitar 121.092 orang $^{6}$. Vonis untuk seorang pemakai seharusnya bukan pidana penjara melainkan harus melaksanakan rehabilitasi.

${ }^{6}$ Ibid

Sri Marthaningtivas, Impilmentasi Kebijakasi Asimilasi... 
Berdasarkan rekomendasi Perserikatan Bangsa-Bangsa (PBB), pengeluaran narapidana dilakukan oleh beberapa negara untuk meminimalisir penyebaran Covid-19. Overcrowding sebesar $75 \%$ di dalam Lapas dan Rutan tidak memungkinkan dilakukannya physical distancing, dan dalam kondisi overcrowded penyakit yang dikategorikan treatable disease bisa menjadi untreatable disease. Dalam kondisi normal (sebelum Covid-19) salah satu penyakit yang banyak ditemui di Rutan/Lapas selain penyakit kulit adalah penyakit yang berkaitan dengan saluran pernafasan (ISPA dan TBC). Pada saat pandemi Covid-19 ini dikuatirkan akan muncul suatu cluster baru di dalam Lapas dan Rutan. Bisa dibayangkan satu orang terkena covid-19, maka seluruh penghuni Lapas dan Rutan yang jumlahnya ratusan bahkan ribuan akan tertular, hal ini akan memperberat pekerjaan Negara terutama tenaga medis.

Dalam laporan UNODC (2020), pengalaman negara lain yang tidak mengeluarkan narapidana dalam kondisi kedaruratan covid-19, antara lain sebagai berikut ${ }^{7}$ :

$\checkmark$ Thailand (Lapas Buriram) sebelum menetapkan kebijakan pengeluaran narapidana, terjadi kerusuhan beberapa narapidana berhasil kabur hal ini dipicu oleh provokasi tentang ancaman merebaknya wabah Covid-19.

$\checkmark$ Italia, terjadi kerusuhan dan pembakaran, beberapa petugas disandera, 7 narapidana meninggal.

$\checkmark$ Kolombia, terjadi kerusuhan yang mengakibatkan sebanyak 23 orang telah tewas di salah satu penjara terbesar di Bogota.

Bercermin dari beberapa negara diatas dan atas rekomendasi PBB, maka beberapa negara akhirnya melakukan pengeluaran Narapidana. Berikut ini beberapa negara yang sudah membuat kebijakan mengeluarkan narapidana di masa pandemic Covid-19:

${ }^{7}$ UNODC, https://wdr.unodc.org/wdr2020/index.html, diakses 01 Oktober 2020 
a. Thailand mengeluarkan 8.000 narapidana (overcrowding 145\%)

b. Afganistan mengeluarkan 10.000 narapidana (overcrowding 179,9\%)

c. Polandia mengeluarkan 9.000-12.000 narapidana (overcrowding $92,9 \%)$

d. Turki mengeluarkan 90.000-100.000 narapidana (overcrowding $118,2 \%)$

e. Iran mengeluarkan 90.000-100.000 narapidana (overcrowding 153\%)

Pemerintah melalui Menteri Hukum dan HAM juga membuat kebijakan pengeluaran asimilasi narapidana saat pandemi covid-19. Berdasarkan kondisi Lapas dan Rutan dengan overcrowded sebesar 103\% menyebabakan pemberlakuan social distancing dan pyshical distancing mustahil dilakukan, oleh sebab itu Menteri Hukum dan HAM RI membuat kebijakan pengeluaran narapidana dan anak melalui asimiliasi di rumah.

\section{Ketentuan Pelaksanaan Asimilasi saat Pandemi Covid-19}

Ketentuan Pelaksanaan Asimiliasi Narapidana di masa pandemi covid-19 ini diatur oleh Menteri Hukum dan an Hak Asasi Manusia melalui Keputusan Menteri Hukum dan Hak Asasi Manusia Nomor M.HH19.PK.01.04.04 Tahun 2020 Tentang Pengeluaran dan Pembebasan Narapidana dan Anak Melalui Asimilasi dan Integrasi dalam rangka Pencegahan dan Penanggulangan Penyebaran Covid-19 dan Peraturan Menteri Hukum Dan Hak Asasi Manusia Republik Indonesia Nomor 10 Tahun 2020 tentang Syarat Pemberian Asimilasi dan Hak Integrasi bagi Narapidana dan Anak dalam rangka Pencegahan dan Penanggulangan Penyebaran Covid-19.

Kebijakan yang dikeluarkan oleh Kementerian Hukum dan HAM ini bertujuan sebagai upaya pencegahan dan penanggulangan penyebaran covid-19 di Lapas dan Rutan dengan melakukan pengaturan pemberian hak asimilasi dan integrasi kepada narapidana dan Anak yang telah memenuhi 
persyaratan untuk dapat melaksanakan Asimilasi, Cuti Menjelang Bebas, Cuti Bersyarat dan Pembebasan Bersyarat, dan pelaksanaan hak asimilasi yang terdapat dalam kebijkan ini harus dilakukan di rumah masing-masing narapidana dan anak. Kebijakan ini dilaksanakan mulai per 1 April 2020.

Kebijakan Pengeluaran asimilasi ini tidak berlaku bagi Narapidana dan Anak yang kategori tindak pidana yang terdapat dalam PP 99 yaitu terorisme, tindak pidana narkotika dan precursor narkotika psikotropika, tindak pidana korupsi, tindak pidana kejahatan terhadap keamanan negara, tindak pidana kejahatan hak asasi manusia yang berat, tindak pidana kejahatan transnasional terorganisasi dan narapidana Warga Negara Asing (WNA).

Pelaksanaan pembimbingan serta pengawasan pengeluaran klien asimilasi dan integrasi karena covid-19 dilakukan oleh Pembimbing Kemasyarakatan (PK) dan Asisten Pembimbing Kemasyarakatan (APK) sesuai dengan Permenkumham No 10 Tahun 2020. Berdasarkan data dari sistem data pemasyarakatan Ditjen Pemasyarakatan per 1 Agustus 2020, narapidana dan anak yang mendapatkan asimilasi dan integrasi karena covid-19 sebanyak 40.330 orang, dengan rincian:

a. 37.910 orang dengan status klien asimilasi yaitu: 36.959 (klien dewasa) dan 951 (klien anak)

b. $\quad 2.420$ orang dengan status klien yang telah mendapatkan integrasi $(\mathrm{CB}, \mathrm{PB}, \mathrm{CMB})$ dari peralihan bimbingan asimilasi.

Berdasarkan data dari sistem data pemasyarakatan Ditjen Pemasyarakatan per 1 Agustus 2020, narapidana dan anak yang melakukan pelanggaran terhadap proses asimilasi dan integrasi karena covid-19 sebanyak 324 orang.

Kebijakan ini secara cepat telah berhasil mengeluarkan kurang lebih 40.330 orang per 1 Agustus 2020 dari Lapas dan Rutan seluruh Indonesia, sehingga turut melonggarkan tingkat over crowded (walaupun 
masih jauh, karena idealnya yang seharusnya dikeluarkan sebanyak 135.000 orang agar kapasitas sesuai dengan jumlah hunian), hal ini dapat dilihat dari database pemasyarakatan, over kapasitas pada bulan Maret sebesar $103 \%$, setelah pelaksanaan kebijakan menurun menjadi $75 \%$.

Selain sedikit dapat memepengaruhi penurunan persentasi overkapasitas/ overcrowded Lapas dan Rutan di Indonesia, dengan adanya pelaksanaan kebijakan ini juga mempengaruhi kualitas tekanan psychososiologis dari narapidana, dimana terjadi penuruan ketakutan/ tingkat stress dari penghuni lapas dan rutan, sehingga mempengaruhi equilibrium tekanan kecemasan yang terjadi pada narapidana disetiap Lapas dan Rutan. Hal ini dapat mencegah terjadinya gangguan keamanan dan ketertiban di dalam Lapas dan Rutan jika terjadi peristiwa penyebaran diantara narapidana dan terbentuk cluster baru dalam Lapas dan Rutan yang dapat menyebabkan kepanikan bagi penghuni yang berakibat pada potensi kerusuhan dikarenakan penghuni takut tertular covid-19, sehingga ada upaya untuk melarikan diri.

Manfaat lain dari pelaksanaan kebijakan ini adalah dalam hal penghematan negara terutama untuk biaya makan narapidana, penghematan anggaran negara sebanyak 40.330orang x 153 hari $\mathrm{x}$ Rp.32.269/ hari $=$ Rp199.115.541.810. Penghematan anggaran ini bisa dimanfaatkan oleh negara untuk penanganan covid-19.

Selain penghematan anggaran Negara, manfaat lain dalam pelaksanaan kebijakan ini juga dirasakan oleh narapidana yang mendapatkan hak asimilasi di rumah, hal ini diungkapkan oleh tiga orang narapidana/ klien pemasyarakatan yang diwawancarai oleh peneliti, pada tanggal 2 Oktober 2020. Ketiga narapidana memberikan jawaban yang sama, mereka menyatakan bahwa mereka sangat bersyukur bisa mendapatkan hak asimilasi di rumah, dan di dekatkan dengan keluarga. 
Mereka berjanji tidak akan mengulangi tindak pidana kembali. Saat awal pengeluaran narapidana, ada perasaan malu di tengah masyarakat, namun dengan adanya keterlibatan peran serta keluarga dalam pelaksanaan asimilasi di rumah sehingga pembimbingan dan pengawasan asimilasi ini dapat berjalan dengan baik. Selain itu keikutsertaan masyarakat dari berbagai lapisan untuk berperan serta dalam menunjang pelaksanaan kebijakan ini. Hal ini bertujuan agar narapidana/ klien pemasyarakatan yang mendapatkan asimilasi di rumah merasa dibutuhkan oleh masyarakat umum, sehingga mereka tidak merasa dikucilkan dan dapat kembali membaur diantara masyarakat pada umumnya.

\section{Kendala pembimbingan dan pengawasan asimilasi narapidana saat covid-19}

Pelaksanaan pembimbingan dan pengawasan bagi narapidana/ klien pemasyarakatan dalam tahap asimilasi masih ada kendala-kendala yang dialami baik oleh petugas pembimbing kemasyarakatan/ asisten pembimbing kemasyarakatan, maupun oleh narapidana itu sendiri. Masyarakat pada umumnya tidak mempedulikan faktor yang menyebabkan mereka melakukan tindak pidana, dan menganggap mereka adalah seseorang yang mengkuatirkan dan tidak mau menerima kehadiran mantan narapidana kembali ke lingkungannya. Faktor penyebab masyarakat tidak menerima narapidana asimilasi ini adalah:

a. Masyarakat kurang siap dan kurangnya kesadaran hukum

b. Adanya suatu pendapat bahwa narapidana adalah seseorang yang melakukan aib dan harus dihukum seberat-beratmnya

c. Adanya kepercayaan terhadap proses pembimbingan dan pengawasan terhadap narapidana yang mendapatkan asimilasi di masa pendemi covid-19. 
d. Adanya rasa curiga dan kekuatiran dari masyarakat bahwa narapidana akan mengulangi perbuatannya.

\section{DAFTAR PUSTAKA}

A. Buku

Mardjono Reksodipoetro, "Hak Asasi Manusia Dalam Sistem Peradilan Pidana: Kumpulan Karangan Buku Ketiga", Jakarta: Pusat Pelayanan Keadilan dan Pengabdian Hukum Universitas Indonesia, 1994

Moeljatno, “Kitab Undang-Undang Hukum Pidana”, Liberty, Yogyakarta, 1978

Muladi dan Barda Nawawi Arief, "Teori-Teori Dan Kebijakan Pidana", Alumni, Bandung, 1992

Petrus Irawan P dan Pandapotan Simorangkir, "Lembaga Pemasyarakatan Dalam Perspektif Sistem Peradilan Pidana", Pustaka Sinar Harapan, Jakarta, 1995

Nawawi Barda, "Bunga Rampai Kebijakan Hukum Pidana: Perkembangan Penyusunan Konsep KUHP Baru”, Kencana, Jakarta, 2008, hlm 48

B. Jurnal

Hari Poerwanto, "Asimilasi, Akulturasi dan Integrasi Nasional", Jurnal Humaniora, Jakarta, ISSN 2302-9269, vol.11: 29-37.

Huang C et al, "Clinical features of patients infected with 2019 novel coronavirus in Wuhan", Lancet China, 2020

C. Internet 
World Health Organization, "Situation Report - 42, https://www.who.int/docs/default-source/coronaviruse/situationreports/20200314-sitrep-54-covid19.pdf?sfvrsn=dcd46351_2, diakses 01 Oktober 2020

World Prison Brief, https://www.prisonstudies.org, diakses 01 Oktober 2020

Website SMS Gateway Kemenkumham:

http://smslap.ditjenpas.go.id/public/grl/current/monthly, diakses 20 Oktober, 2020

UNODC, https://wdr.unodc.org/wdr2020/index.html, diakses 01 Oktober 2020

D. Peraturan Perundang-Undangan

Undang-Undang RI Nomor 12 Tahun 1995 tentang Pemasyarakatan;

Peraturan Menteri Hukum dan HAM RI No.10 Tahun 2020 tentang Syarat Pemberian Asimilasi dan Hak Integrasi bagi Narapidana dan Anak dalam Rangka Pencegahan dan Penanggulangan Penyebaran COVID-19;

Peraturan Menteri Hukum Dan Hak Asasi Manusia Republik Indonesia Nomor 03 Tahun 2018 Tentang Syarat Dan Tata Cara Pemberian Remisi, Asimilasi, Cuti Mengunjungi Keluarga, Pembebasan Bersyarat, Cuti Menjelang Bebas, Dan Cuti Bersyarat 